\title{
HUBUNGAN ANTARA KECAKAPAN LITERASI DIGITAL DENGAN KREATIVITAS MENGAJAR GURU DALAM KEGIATAN PEMBELAJARAN
}

\author{
Muhammad Wajdi ${ }^{*}$ \\ Tasrif Akib ${ }^{2}$ \\ M. Natsir ${ }^{3}$ \\ Edi Hasan ${ }^{4}$ \\ Abidin $^{5}$ \\ ${ }^{1,2}$ Universitas Muhammadiyah Makassar, Makassar, Indonesia \\ 3,4,5 Prodi Keperawatan, Poltekkes Kemenkes Makassar, Indonesia \\ muh.wajdi@unismuh.ac.id ${ }^{\left.1^{*}\right)}$ \\ tasrifakib@unismuh.ac.id ${ }^{2}$ \\ mnatsir@poltekkes-mks.ac.id ${ }^{3}$ \\ edihasan@poltekkes-mks.ac.id ${ }^{3}$ \\ abidinpare@poltekkes-mks.ac.id ${ }^{4}$
}

\begin{abstract}
Abstrak
Penelitian ini bertujuan untuk mengetahui hubungan antara kecakapan literasi digital guru dengan kreativitas mengajar guru pada Sekolah Menegah Kejuruan Negeri di Kabupaten Gowa. Penelitian ini menggunakan metode survei yang bersifat korelasi dengan pendekatan kuantitatif. Populasi dalam penelitian yaitu guru yang berstatus Pegawai Negeri Sipil yang terdapat pada 5 Sekolah Menengah Kejuruan Negeri di Kabupaten Gowa dan sebanyak 70 orang guru yang menjadi sampel melalui tekni proportional random sampling pada setiap unit populasi dalam memperoleh data penelitian. Pengumpulan data penelitian ini menggunakan kuesioner skala likeart yang telah memenuhi syarat validitas dan reabilitas. Teknik analisis data untuk mencapai tujuan penelitian menggunakan statistik inferensial yakni analisis korelasi sederhana. Hasil penelitian mengungkapkan bahwa berdasarkan nilai pearson correlation yang diperoleh dari analisis korelasi sederhana sebesar 0,731 dengan arah positif dan nilai sig.p $0,00<\alpha(0,05)$ yang memberikan pengertian bahwa terdapat hubungan positif dan signifikan antara kecakapan literasi digital guru dengan kreativitas mengajar guru pada Sekolah Menegah Kejuruan Negeri di kabupaten Gowa, serta diperoleh nilai koefisien determinasi sebesar 53\% yang dapat diartikan bahwa 53\% variansi total nilai-nilai kreativitas mengajar guru dapat dijelaskan oleh nilai-nilai kecakapan literasi digital guru.
\end{abstract}

Kata Kunci: Kecakapan Literasi Digital, Kegiatan Pembelajaran, Kreativitas Mengajar Guru

Published by:

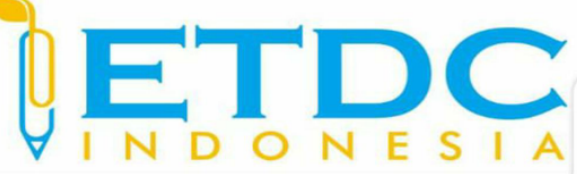

Copyright (C) 2021 The Author (s)

This article is licensed under CC BY 4.0 License

(cc) $\mathrm{BY}$ 


\section{HUBUNGAN ANTARA KECAKAPAN LITERASI DIGITAL DENGAN KREATIVITAS MENGAJAR GURU DALAM KEGIATAN PEMBELAJARAN}

\section{Pendahuluan}

Dalam mendesain Pendidikan yang berkualitas hendaknya sejalan dengan perkembangan dan kemajuan teknologi yang saat ini telah berkembang. Pada abad ke-21 saat ini perkembangan teknologi digital dibidang pendidikan semakin maju, hal tersebut dapat menjadi pertimbangan guru sebagai salah satu strategi dalam mengembangkan proses pembelajaran. Pemanfaatan teknologi digital dalam pembelajaran terlebih dahulu guru dituntut untuk aktif terhadap segala teknologi informasi dan perkembangan digital.

Seorang guru harus mahir untuk memanfaatkan inovasi teknologi dalam menyampaikan dan mendukung pembelajaran disekolah, guru perlu menciptakan pembelajaran komputerisasi yang memanfaatkan inovasi teknologi, guru dengan peserta didik harus menggunakan teknologi digital dalam menfasilitasi pembelajaran (Ally, 2019). Literasi digital merupakan kecakapan yang diharapkan dimiliki oleh guru agar dapat menggunakan beragam teknologi digital dalam pembelajaran (Asari et al., 2019). Bahkan (Falloon, 2020) mengungkapkan bahwa dalam proses pendidikan dimasa depan kompetensi literasi digital sangat dibutukan oleh seorang guru dalam mengelolah pembelajaran.

Perkembangan teknologi digital dapat dimanfaatkan dalam bidang pendidikan, khususnya dalam pelaksanaan kegiatan belajar mengajar agar tercapai keberhasilan tujuan pendidikan (Rizal et al., 2019). kecakapan literasi digital diartikan sebagai keterampilan untuk memahami karakteristik dan fitur teknologi digital dan pengaruh identitas digital, memiliki kemampuan untuk mengelola, memahami, menilai, dan mengomunikasikan informasi menggunakan teknologi digital serta berinteraksi di dunia digital dengan aman(Kurniawati et al., 2018).

Komponen lain dalam melaksanakan tugas keprofesionalan seorang guru khususnya dalam proses pembelajaran yaitu kreativitas guru dalam mengajar (Juandi \& Sontani, 2017). Kreativitas guru dalam mengelola pembelajaran merupakan salah satu bentuk tuntutan sebagai tenaga profesional seorang guru (Febriandar, 2018). Akan tetapi, persiapan yang maksimal belum tentu menghasilkan pembelajaran yang optimal, karena hal tersebut bisa saja dipengaruhi oleh faktor tertentu. (Mullet et al., 2016) mengungkapkan bahwa kreativitas guru dalam mengajar merupakan hal yang penting karena akan membawa suasana yang hidup dalam pembelajaran. Kreativitas mengajar guru adalah kecakapan guru dalam mengembangkan bahan 
dan materi pelajaran serta dapat menciptakan suasana yang menarik perhatian peserta didik dalam pembelajaran (Pentury, 2017)

Salah satu faktor yang mempengaruhi prestasi belajar siswa adalah kreativitas guru dalam mengajar (Rasam \& Sari, 2018) dan dalam proses pembelajaran terdapat ruang improvisasi dan ruang pengembangan kreativitas yang seyogyanya dilakukan oleh guru karena proses mengajar menggunakan pendekatan imajinatif untuk membuat kegiatan pembelajaran yang menarik (Cayirdag, 2017). Olehnya itu, guru seyogyanya meningkatkan kreativitasnya dalam proses belajar mengajar menjadi lebih baik dan menyenangkan sehingga siswa dapat dengan mudah dan tertarik dalam mengikuti proses pemmbelajaran (Herawati et al., 2019).

Bidang pendidikan di Indonesia saat ini dihadapkan dengan tantangan ditengah mewabahnya virus Covid-19. Dengan mewabahnya virus Covid-19 tersebut, pemerintah membuat sebuah kebijakan yang menganjurkan dalam melaksanakan proses pembelajaran hendaknya dilakukan secara daring atau jarak jauh tanpa adanya tatap muka secara langsung (Indrawati, 2020). Diberlakukannya pembelajaran daring membuat sistem pembelajaran disekolah berubah dari pertemuan tatap muka menjadi pembelajaran daring atau jarak jauh yang tentunya mengandalkan piranti teknologi dalam proses pelaksanaannya. Seperti halnya pada Sekolah Menengah Kejuruan Negeri yang terdapat di Kabupaten Gowa, dimana proses belajar mengajar dilaksanakan secara jarak jauh atau daring. Berdasarkan hasil observasi yang dilakukan mengenai adanya kebijakan pembelajaran secara daring atau jarak jauh tersebut, guru-guru dikehendaki untuk lebih interaktif memanfaatkan teknologi digital dalam proses pembelajaran. Hal tersebut tentunya diperlukan kecakapan teknologi khususnya kecakapan literasi digital bagi guru agar proses pembelajaran bisa berjalan dengan efektif ditengah pandemi Covid-19 dan tentunya dibutuhkan kreativitas mengajar guru dalam pembelajaran.

Dengan menerapkan pembelajaran daring sebagai salah satu alternatif pembelajaran ditengah pandemi Covid-19 saat ini, maka kecakapan literasi digital dan kreativitas guru dalam mengajar mutlak dibutuhkan dan harus dimiliki guru. Hal ini karena mustahil menerapkan pembelajaran daring ditengah mewabahnya virus Covid-19 tanpa ditunjang oleh kecakapan literasi digital dan kreativitas guru dalam mengajar. Olehnya itu dilakukanlah penelitian yang bertujuan untuk mengetahui hubungan kecakapan literasi digital guru dengan kreativitas mengajar guru pada Sekolah Menegah Kejuruan Negeri Di Kabupaten Gowa.

\section{Metode Penelitian}

Penelitian ini menggunakan pendekatan kuantitatif dengan metode survei yang bersifat korelasi yang dilaksanakan pada Sekolah Menegah Kejuruan Negeri di Kabupaten Gowa 
sebanyak 5 Sekolah Negeri. Populasi dalam penelitian ini adalah seluruh guru yang berstatus Pegawai Negeri Sipil yang berjumlah 238 guru. Penentuan jumlah sampel menggunakan rumus slovin sehingga diperoleh jumlah sampel sebanyak 70 guru. Untuk memperoleh sampel dalam penelitian ini menggunakan teknik proporsial random sampling pada setiap unit populasi. Variabel dalam penelitian ini yaitu, kecakapan literasi digital guru (X) dan kreativitas mengajar guru (Y). berikut disajikan desain penelitian ini:

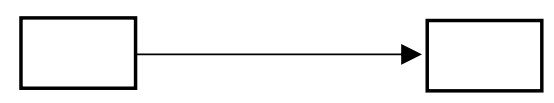

Gambar 1. Desain Penelitian

Teknik pengumpulan data diperoleh dengan menggunakan kuesioner skala likeart yang sebelumnya akan diuji validitasnya berdasarkan validitas teoritik dan validitas empirik serta reabilitasnya. Teknik analisis data yang digunakan dalam penelitian ini menggunakan statistik inferensial korelasi moment pearson. $\mathrm{H} 1$ dalam penelitian ini yaitu terdapat hubungan positif dan signifikan antara kecakapan literasi digital guru dengan kreativitas mengajar guru pada Sekolah menengah kejuruan Negeri di Kabupaten Gowa dengan $\alpha=0,05$. Pengujian dilakukan dengan bantuan program SPSS 20.

\section{Hasil dan Pembahasan}

\subsection{Pengujian Validitas Teoritik dan Empirik}

Pengujian Validitas Teoritik ini meliputi validitas isi instrumen yang dikembangkan dengan menggunakan model pengujian Gregory yang memperhatikan pendapat dua pakar (Gregory, 2014) hasil pengujian diperoleh nilai koefisien konsistensi internal sebesar 1 untuk instrumen literasi digital guru dan nilai koefisien konsistensi internal sebesar 1 untuk instrumen kreativitas mengajar guru. Sehungan dengan nilai koefisien konsistensi internal dari setiap instrument $>0,75$ sehingga kedua instrument tersebut telah valid berdasarkan uji validitas teoritik.

Selanjutnya dalam pengujian validitas instrumen secara emprik yang berdasarkan hasil uji coba terhadap 30 responden yang dianggap setara yaitu dengan membanding nilai koefisien korelasi anatra skor butir dengan skor total (r hitung) dan $r$ tabel (30 Setiap butir dikatakan valid jika $\mathrm{r}$ hitung $>\mathrm{r}$ tabel (Sugiyono, 2015). Berikut disajikan hasil pengujian untuk setiap instrumen (Lihat Tabel 1). 
Tabel 1. Pengujian Validitas Instrumen Literasi Digital Guru

\begin{tabular}{cccc}
\hline No. Butir & r hitung & $\mathrm{r}$ tabel $(\mathrm{n}=30)$ & Keterangan \\
\hline 1 & 0,76 & 0,36 & Valid \\
2 & 0,80 & 0,36 & Valid \\
3 & 0,79 & 0,36 & Valid \\
4 & 0,76 & 0,36 & Valid \\
5 & 0,76 & 0,36 & Valid \\
6 & 0,79 & 0,36 & Valid \\
7 & 0,80 & 0,36 & Valid \\
8 & 0,79 & 0,36 & Valid \\
9 & 0,37 & 0,36 & Valid \\
10 & 0,46 & 0,36 & Valid \\
11 & 0,79 & 0,36 & Valid \\
12 & 0,76 & 0,36 & Valid \\
13 & 0,80 & 0,36 & Valid \\
14 & 0,80 & 0,36 & Valid \\
15 & 0,76 & 0,36 & Valid \\
\hline
\end{tabular}

Tabel 2. Pengujian Validitas Instrumen Kreativitas Mengajar Guru

\begin{tabular}{crcc}
\hline No. Butir & r hitung & r tabel $(\mathrm{n}=30)$ & Keterangan \\
\hline 1 & 0,64 & 0,36 & Valid \\
2 & 0,82 & 0,36 & Valid \\
3 & 0,82 & 0,36 & Valid \\
4 & 0,70 & 0,36 & Valid \\
5 & 0,70 & 0,36 & Valid \\
6 & 0,82 & 0,36 & Valid \\
7 & 0,82 & 0,36 & Valid \\
8 & 0,82 & 0,36 & Valid \\
9 & 0,38 & 0,36 & Valid \\
10 & 0,82 & 0,36 & Valid \\
11 & 0,82 & 0,36 & Valid \\
12 & 0,82 & 0,36 & Valid \\
13 & 0,82 & 0,36 & Valid \\
14 & 0,82 & 0,36 & Valid \\
15 & 0,64 & 0,36 & Valid \\
\hline
\end{tabular}

\subsection{Pengujian Reabilitas Instrumen}

Pengujian reabilitas instrument ini menggunakan rumus alpha Cronbach dengan ketentuan instrumen dikatakan reliabel jika nilai reabilitas $>0,70$ (Ghozali, 2011). Berikut disajikan hasil perhitungan (Lihat Tabel 3).

Tabel 3. Hasil Perhitungan Reabilitas

\begin{tabular}{lcc}
\hline \multicolumn{1}{c}{ Instrumen } & Nilai & Keterangan \\
\hline Literasi digital guru & 0,92 & Reliabel \\
Kreativitas Mengajar Guru & 0,91 & Reliabel \\
\hline
\end{tabular}




\subsection{Uji Prasyarat}

\section{a. Hasil Uji Normalitas}

Dalam pengujian Normalitas data yang diperoleh menggunakan metode KolmogorovSmirnov dengan bantuan program SPSS 20. Berikut hasil Uji-Normalitas (Lihat Tabel 4).

Tabel 4. Kolmogorov-Smirnov Test

\begin{tabular}{lll}
\hline \multirow{2}{*}{$\mathrm{N}$} & KLDG & KMG \\
\cline { 2 - 3 } Kolmogorov-Smirnov Z & 70 & 70 \\
Asymp. Sig. (2-tailed) & 1.349 & .893 \\
\hline
\end{tabular}

Berdasarkan pengujian dengan taraf signifikansi $\alpha=0,05$ yang tersaji pada tabel diatas diperoleh nilai signifikasi $0,354>\alpha$ untuk data literasi digital guru dan nilai signifikansi $0,797>\alpha$ untuk data kreativitas mengajar guru sehingga disimpulkan bahwa kedua data pada penelitian ini telah berdistribusi normal

\section{b. Hasil Uji Linearitas}

Berikut hasil uji linearitas dengan bantuan program SPSS 20 dengan taraf signifikansi $\alpha=0,05$.

Tabel 5. Tabel Anova

\begin{tabular}{ll}
\hline Anova Tabel & Sig \\
\hline deviation from linearity & 0,523
\end{tabular}

Berdasarkan perhitungan yang disajikan pada tabel diatas, diperoleh nilai sig $=0,69$ pada kolom deviation from linearity. Hasil perhitungan tersebut menunjukan bahwa nilai sig $>$ $\operatorname{sig} \alpha(0,05)$. Hasil tersebut menyimpulkan bahwa terjadi hubungan yang linear antara variabel kecakapan literasi digital guru (X) dengan variabel kreativitas mengajar guru (Y) pada penelitian ini

\section{c. Hasil Pengujian Korelasi Pearson dan uji Hipotesis}

Berikut disajikan hasil perhitungan dan pengujian dalam penelitian ini.

Tabel 6. Hasil Pengujian

\begin{tabular}{|c|c|c|c|}
\hline & & $\begin{array}{l}\text { Literasi } \\
\text { Digital } \\
\text { Guru }\end{array}$ & $\begin{array}{l}\text { Kreativitas mengajar } \\
\text { Guru }\end{array}$ \\
\hline Literasi & $\begin{array}{l}\text { Pearson } \\
\text { Correlation }\end{array}$ & 1 & $.731^{* *}$ \\
\hline Digital guru & Sig. (2 tailed $)$ & 70 & $\begin{array}{r}.000 \\
70\end{array}$ \\
\hline $\begin{array}{l}\text { Kreativitas } \\
\text { mengajar } \\
\text { guru }\end{array}$ & $\begin{array}{l}\text { Pearson } \\
\text { Correlation } \\
\text { Sig. (2 tailed }) \\
N\end{array}$ & $\begin{array}{r}.731^{* *} \\
.000 \\
70\end{array}$ & 70 \\
\hline
\end{tabular}

Berdasarkan hasil perhitungan menggunakan teknik korelasi moment pearson dengan 
bantuan program SPSS 20 yang disajikan pada tabel diatas diperoleh nilai koefisien korelasi sebesar 0,731 dengan arah yang positif dan diperoleh nilai sig.p $(0,00)<\alpha(0,05)$. Hasil tersebut menunjukan bahwa H0 dalam penelitian ini ditolak dan $\mathrm{H} 1$ dalam penelitian ini diterima sehingga hasil pengujian tersebut mengungkapkan bahwa terdapat hubungan yang positif dan signifikan antara kecakapan literasi digital guru (X) dengan kreativitas mengajar guru pada Sekolah Menengah Kejuruan Negeri di Kabupaten Gowa. Selanjutnya untuk menjelaskan seberapa besar variansi dari variabel kreativitas mengajar guru (Y) dapat diterangkan atau dijelaskan oleh variabel kecakapan literasi digital guru (X), dapat dijelaskan oleh perolehan koefisien determinan $\left(\mathrm{R}^{2}\right)$ sebesar $0,73 \times 0,73=0,53$ atau 53\%. Hasil peroleh koefisien determinasi yang sebesar 53\% tersebut dapat diartikan bahwa 53\% variansi total nilai-nilai kreativitas mengajar guru (Y) dapat dijelaskan oleh nilai-nilai kecakapan literasi digital guru $(\mathrm{X})$.

\subsection{Pembahasan}

Berdasarkan hasil analisis dan pengujian yang telah di lakukan, terungkap bahwa terdapat hubungan yang positif dan signifikan antara kecakapan literasi digital guru dengan kreativitas mengajar guru serta hasil koefisien determinasi sebesar 53\% yang menjelaskan bahwa 53\% variansi total nilai-nilai kreativitas mengajar guru (Y) dapat dijelaskan oleh nilainilai kecakapan literasi digital guru (X). Hasil tersebut mengungkapkan bahwa kecakapan literasi digital guru memiliki peranan penting dan sangat berarti dalam kreativitas mengajar guru dalam preses pembelajaran. Peranan tersebut dapat mengandung makna bahwa semakin baik kecakapan literasi digital guru maka akan semakin menunjang serta meningkatkan kreativitas mengajar guru dalam kegiatan pembelajaran. Tentunya setiap guru perlu memahami bahwa cakap berliterasi digital merupakan hal yang penting dalam proses pembelajaran karena dengan cakap berliterasi digital akan menciptakan tatana guru yang kreatif dan inovatif (Kemdikbud, 2017).

Hasil penelitian yang dilakukan ini relevan dengan temuan (Harjono, 2019) dalam penelitiannya yang mengungkapkan bahwa penguasaan literasi digital dalam pembelajaran yang dilakukan guru dapat menguatkan proses pembelajaran dan pendidikan, kemudian penelitian yang dilakukan (Rahmawati \& Yulianti, 2020) yang mengungkapkan bahwa kreativitas mengajar guru dalam proses pembelajaran ditengah pandemi Covid-19 tidak dapat terlepas dari penggunaan teknologi digital.

Olehnya itu, berdasarkan temuan yang diperoleh dalam penelitian ini hendaknya guru lebih banyak belajar mengembangkan kecakapan literasi digital dan mengembangkan kreativitasnya dalam kegiatan belajar dan mengajar (KBM) agar proses belajar mengajar di 
sekolah bisa tetap efektif dan tujuan pendidikan tetap dapat tercapai ditengah pandemi Covid19

\section{Kesimpulan}

Berdasarkan hasil dan pembahasan pada penelitian ini disimpulkan bahwa terdapat hubungan positif dan signifikan antara kecakapan literasi digital guru dengan kreativitas mengajar guru pada Sekolah Menenegah Kejuruan Negeri di Kabupaten Gowa dengan derajat hubungan sebesar 0,731, artinya semakin baik literasi digital guru maka akan semakin baik pula kreativitasnya dalam mengajar di tengan pandemi Covid-19 dimana sistem pembelajaran dilaksanakan secara jarak jauh atau daring. Olehnya itu dapat di implikasikan bahwa dalam proses pembelajaran yang dilakukan oleh guru ditengah pandemi Covid-19 saat ini hendaknya guru untuk meningkatkan kecakapan literasi digital dan kreativitasnya dalam mengajar.

\section{DAFTAR PUSTAKA}

Ally, M. (2019). International Review of Research in Open and Distributed Learning Competency Profile of the Digital and Online Teacher in Future Education. International Review of Research in Open and Distributed Learning Competency, 20(2), 303-318. Diambil dari https://id.erudit.org/iderudit/1061343ar

Asari, A., Kurniawan, T., Ansor, S., Bagus, A., \& Rahma, N. (2019). Kompetensi Literasi Digital Bagi Guru Dan Pelajar Di. BIBLIOTIKA: Jurnal Kajian Perpustakaan dan Informasi, 3, 98-104.

Cayirdag, N. (2017). Creativity fostering teaching: Impact of creative self-efficacy and teacher efficacy. Kuram ve Uygulamada Egitim Bilimleri, 17(6), 1959-1975. https://doi.org/10.12738/estp.2017.6.0437

Falloon, G. (2020). From digital literacy to digital competence: the teacher digital competency (TDC) framework. Educational Technology Research and Development, 68(5), 24492472. https://doi.org/10.1007/s11423-020-09767-4

Febriandar, E. I. (2018). Pengaruh Kreativitas Guru Dalam Menerapkan Ice Breaking Dan Motivasi Belajar Terhadap Hasil Belajar Siswa Sekolah Dasar. Briliant: Jurnal Riset dan Konseptual, 3(4), 498. https://doi.org/10.28926/briliant.v3i4.253

Ghozali, I. (2011). Aplikasi Analisis Multivariat dengan Program SPSS. Semarang: Badan Penerbit Universitas Diponegoro.

Gregory, R. J. (2014). Psychological testing: History, principles, and applications. Psychological Testing. England: Pearson Education.

Harjono, H. S. (2019). Literasi Digital: Prospek dan Implikasinya dalam Pembelajaran Bahasa. Pena: Jurnal Pendidikan Bahasa dan Sastra, 8(1), 1-7. 


\section{https://doi.org/10.22437/pena.v8i1.6706}

Herawati, R., Mujahidin, E., \& Hamat, A. Al. (2019). Hubungan Motivasi Dan Kreativitas Guru Dalam Mengajar Dengan Hasil Belajar Mata Pelajaran Pai Di Madrasah Aliyah Negeri 4 $\begin{array}{llll}\text { Bogor. Jurnal Teknologi } & \text { P(2), }\end{array}$ https://doi.org/10.32832/tek.pend.v8i2.1507

Indrawati, B. (2020). Tantangan dan Peluang Pendidikan Tinggi Dalam Masa dan Pasca Pandemi Covid-19. Jurnal Kajian Ilmiah, 1(1), 39-48. https://doi.org/10.31599/jki.v1i1.261

Juandi, A., \& Sontani, U. T. (2017). Keterampilan Dan Kreativitas Mengajar Guru Sebagai Determinan Terhadap Prestasi Belajar Siswa. Jurnal Pendidikan Manajemen Perkantoran, 2(2), 130. https://doi.org/10.17509/jpm.v2i2.8114

Kemdikbud. (2017). Konsep Literasi Digital dalam Kurikulum 2013. Konsep Literasi Digital dalam Kurikulum 2013. Jakarta: Pusat Kurikulum dan Perbukuan Kemdikbud.

Kurniawati, N., Maolida, E. H., \& Anjaniputra, A. G. (2018). The praxis of digital literacy in the EFL classroom: Digital-immigrant vs digital-native teacher. Indonesian Journal of Applied Linguistics, 8(1), 28-37. https://doi.org/10.17509/ijal.v8i1.11459

Mullet, D. R., Willerson, A., N. Lamb, K., \& Kettler, T. (2016). Examining teacher perceptions of creativity: A systematic review of the literature. Thinking Skills and Creativity, 21, 930. https://doi.org/10.1016/j.tsc.2016.05.001

Pentury, H. J. (2017). Pengembangan Kreativitas Guru dalam Pembelajaran Kreatif Pembelajaran Bahasa Inggris. Jurnal Ilmu Kependidikan, 4(3), 265-272.

Rahmawati, I. Y., \& Yulianti, B. (2020). Kreativitas guru dalam proses pembelajaran ditinjau dari penggunaan metode pembelajaran jarak jauh di tengah wabah. AL-ASASIYYA: Journal Basic of Education, 5(1), 27-39. Diambil dari http://journal.umpo.ac.id/index.php/alasasiyya/index

Rasam, F., \& Sari, A. I. C. (2018). Peran Kreativitas Guru Dalam Penggunaan Media Belajar Dan Minat Belajar Dalam Meningkatkan Prestasi Belajar Peserta Didik Smk Di Jakarta Selatan. Research and Development Journal of Education, 5(1), 95. https://doi.org/10.30998/rdje.v5i1.3391

Rizal, R., Setiawan, W., \& Rusdiana, D. (2019). Digital literacy of preservice science teacher. Journal of Physics: Conference Series, 1157(2). https://doi.org/10.1088/1742$\underline{6596 / 1157 / 2 / 022058}$

Sugiyono. (2015). Metode penelitian Kuantitatif, Kualitatif dan R\&D. Bandung: Alfabeta. 